\title{
THE INFLUENCE OF THE ENDOGENOUS AND EXOGENOUS FACTORS ON CREDIT INSTITUTIONS' RETURN ON EQUITY
}

\author{
Professor Nicolae Baltes PhD \\ "Lucian Blaga" University, Sibiu, Romania, Faculty of Economics \\ E-mail: baltes_n@yahoo.com \\ Maria-Daciana Rodean (Cozma) PhD Student \\ "Lucian Blaga" University, Sibiu, Romania, Faculty of Economics \\ E-mail: maria.daciana89@yahoo.com
}

(Received February 2015; accepted April 2015)

\begin{abstract}
:
The research's purpose is to study the credit institutions' performance, from the shareholders' point of view, through return on equity (ROE). It aims to identify a dependency relationship between return on equity (ROE) and endogenous factors (the growth rate of credit portfolio, the growth rate provisions, the solvency ratio), on the one hand and, on the other hand between ROE and the exogenous ones (GDP and inflation rate). The research was done over an horizon of 10 years (2004-2013) on the evolution of the return on equity indicator of two credit institutions listed on Bucharest Stock Exchange (Carpathian Commercial Bank SA and Banca Transilvania SA), highlights their vulnerability to economic conditions. The results obtained indicates, that in both credit institutions, the variation of return on capital is determined in a significant proportion by intern factors and it is conditioned in a insignificant share by the exogenous factors.
\end{abstract}

Keywords: ROE, endogenous and exogenous factors, profitability, multiliniar regression, credit institution

JEL Classification: G32

REL Classification: $11 \mathrm{C}, 14 \mathrm{~K}$;

\section{Introduction}

The performance of a credit institution is closely monitored by its shareholders, its creditors, its supervisors, etc., providing an image on the management's effectiveness. Return on equity of a credit institution (ROE) is a closely monitored indicator of performance in current market conditions. Specifically, ROE provides information on the profitability registered by a credit institution on an accounting unit of the investment made by a shareholder in it. To determine this factor it is taken into account two elements, namely: the net profit and equity's level.

\section{Literature review}

The study of ROE is a subject discussed extensively in the literature review, due to the importance of this indicator in adopting effective decisions by the managers in order to continue credit institution's activity. 
Baltes, N. , Rodean (Cozma), M.D., (2015)

The influence of endogenous and exogenous factors on credit insitutions 'return on equity

According to a study made by Rajan in 2005, an accurate assessment of one commercial bank' performance is a complicated requirement, due to the necessity of a clear establishing obtained performance able to create a real value for shareholders. It is shown that high levels of performance can always be obtained only by taking major risks.

The researchers Navapan and Tripe in a study done in 2003, identified that an assessing method of the performance of a bank is represented by the comparison of the rates of return obtained by the banks of the same size. Through the same study it was demonstrated that there is a reverse relationship between the solvency ratio and ROE. In 2004, in his study the researcher Thampy demonstrated the impact of capital adequacy in accordance with the regulations imposed on credit growth.

A positive relationship between GDP and return on equity was identified into a study conducted in 2011, by Shaher, Kasawneh and Salem. Also in 2012, Zeituni analyzed the influence of the macroeconomic factors on banks that are operating in the Gulf Cooperation Council. The results showed that between GDP and ROE exists a linear relationship, while between inflation and ROE it was identified a reverse relationship.

\section{Data's and methodology}

The purpose of this research is to identify the dependency relationship between the indicator of profitability (ROE) and internal and external determinants of banking environment. In this study, internal determinants that have been taking into account are: the growth rate of the loan portfolio; the growth rate provisions and the solvency ratio, while the external determinants of the banking environment are: GDP and the inflation rate.

The study was conducted on two credit institutions listed on BSE: Carpatica Commercial Bank and Banca Transilvania SA. It were used the results of the two banks obtained during 2004-2013, taken from the financial statements and annual reports. The database for the external determinants (GDP and inflation) was formed using the website of the National Institute of Statistics (www.insse.ro). The data's were processed using statistical and mathematical software Microsoft Excel. In order to identify the dependency relationship it was used the multiline regression, Student and F tests.

The multivariate prediction model is, according to the statistician Mihai Popa (http://www.mpopa.ro/statistica_master/05_statm_regresia\%20mutipla.pdf), the following formula:

where:

$$
f(x)=a_{0}+\sum_{i=1}^{\infty} b_{i} * x_{i}
$$

$f(x)$ - the estimated value for the dependent variable,

$\mathrm{a}_{0}$ - the origin of the line (constant) 
Baltes, N. , Rodean (Cozma), M.D., (2015)

The influence of endogenous and exogenous factors on credit insitutions 'return on equity

$\mathrm{b}_{\mathrm{i}}-\mathrm{b}$ coefficient for the predictor variable $\mathrm{k}$

$\mathrm{x}_{\mathrm{i}}-\mathrm{k}$ variables of predictor variables

In order to identify the dependency relationship between return on equity of both credit institutions and the endogenous factors it started from the following model:

where:

$$
R O E=\alpha_{0}+\alpha_{1} * R G L P+\alpha_{2} * R G P+\alpha_{3} * S_{R,}
$$

ROE - Return on equity;

$\alpha$ - Percentage contribution rate fluctuation growth of the loan portfolio (RCPC), growth rates provisions (SPC) and the solvency ratio (Is) to the variation of the return on assets;

$\mathrm{S}_{\mathrm{r}}$ - indicator of solvency;

RGLP - Growth rate of the loan portfolio;

RGP - growth rate provisions.

The dependency relationship between return on equity (ROE) and external determinants was determined based on the following model:

where:

$$
\mathbf{R O E}=\alpha_{0}+\alpha_{1}^{*} \mathbf{G D P}+\alpha_{2} * \mathbf{R}_{\mathbf{i}}
$$

ROE - Return on equity;

$\alpha$-Percentage contribution rate fluctuation of the Gross Domestic Product, inflation rate;

GDP - Gross Domestic Product;

$\mathrm{Ri}$ - inflation rate.

\section{Study on the impact of internal determinants over the Carpathian Commercial Bank and Transilvania Bank' return on equity}

The two credit institutions were established almost in the same period (1999 - in case of Carpathian Bank (CCB), 1994 -in case of Transilvania Bank-BT), the adopted strategy by the two credit institutions and also the obtained results are significantly different. The evolution of the return on equity ratio (ROE) recorded by the two credit institutions during 2004-2013 is summarized in Table. 1.

\section{Tabel no. 1- The evolution of the return on equity during 2004-2013 (\%)}

\begin{tabular}{|c|c|c|c|c|c|c|c|c|c|c|}
\hline $\begin{array}{c}\text { Indicator / } \\
\text { Year }\end{array}$ & $\mathbf{2 0 1 3}$ & $\mathbf{2 0 1 2}$ & $\mathbf{2 0 1 1}$ & $\mathbf{2 0 1 0}$ & $\mathbf{2 0 0 9}$ & $\mathbf{2 0 0 8}$ & $\mathbf{2 0 0 7}$ & $\mathbf{2 0 0 6}$ & $\mathbf{2 0 0 5}$ & $\mathbf{2 0 0 4}$ \\
\hline ROE -BCC & 9,8 & 5,95 & - & - & - & 0,34 & 4,15 & 12,14 & 11,3 & 11,29 \\
\hline ROE - BT & 13,78 & 12,51 & 6,38 & 5,33 & 3,64 & 23,16 & 28,1 & 17,14 & 20,97 & 20,27 \\
\hline
\end{tabular}

Source: data's processed by the authors based on the Carpathian Bank and Transilvania Bank' financial statements during 2004-2013 
Baltes, N. , Rodean (Cozma), M.D., (2015)

The influence of endogenous and exogenous factors on credit insitutions 'return on equity

From Table no 1 it can be seen that the performance recorded by Transilvania Bank is superior to the one registered by Carpathian Commercial Bank. However, during the economic crisis, both banks decreased their profitability, BCC even recording losses during 2009-2011. Since 2012, the indicator came on an upward trend in both credit institutions. These evolutions are mainly due to distinct strategy adopted by the two banks, to the loan portfolio which they have formed and managed, and also because of the policy adopted during the crisis.

The results of the multiliniar regression model for BCC are summarized in Table 2.

Tabel no. 2 - The results of the multiliniar regression model - ROE-internal determinants in case of $\mathrm{BCC}$

\begin{tabular}{|c|c|c|c|c|c|c|c|c|}
\hline \multicolumn{2}{|c|}{ Regression Statistics } & & & \\
\hline Multiple R & 0,93 & & & & & & & \\
\hline R Square & 0,87 & & & & & & & \\
\hline Adjusted R Square & 0,81 & & & & & & & \\
\hline Standard Error & 2,29 & & & & & & & \\
\hline Observations & 10 & & & & & & & \\
\hline ANOVA & & & & & & & & \\
\hline & $d f$ & SS & $M S$ & $F$ & Signifi & nce F & & \\
\hline Regression & 3 & 217,73 & 72,58 & 13,86 & & & & \\
\hline Residual & 6 & 31,41 & 5,24 & & & & & \\
\hline Total & 9 & 249,14 & & & & & & \\
\hline & Coefficients & $\begin{array}{c}\text { Standard } \\
\text { Error }\end{array}$ & $t$ Stat & $\begin{array}{c}P- \\
\text { value }\end{array}$ & $\begin{array}{c}\text { Lower } \\
95 \%\end{array}$ & $\begin{array}{c}\text { Upper } \\
95 \%\end{array}$ & $\begin{array}{l}\text { Lower } \\
95.0 \% \\
\end{array}$ & $\begin{array}{l}\text { Upper } \\
95.0 \% \\
\end{array}$ \\
\hline Intercept & 3,79 & 2,21 & 1,72 & 0,14 & $-1,61$ & 9,19 & $-1,61$ & 9,19 \\
\hline $\begin{array}{l}\text { Growth rate } \\
\text { of the loan } \\
\text { portfolio }\end{array}$ & 0,07 & 0,01 & 4,55 & 0,00 & 0,03 & 0,10 & 0,03 & 0,10 \\
\hline $\begin{array}{l}\text { The growth } \\
\text { rate of } \\
\text { provisions }\end{array}$ & $-0,06$ & 0,02 & $-3,43$ & 0,01 & $-0,10$ & $-0,02$ & $-0,10$ & $-0,02$ \\
\hline $\begin{array}{l}\text { Solvency } \\
\text { ratio }\end{array}$ & 0,19 & 0,09 & 2,07 & 0,08 & $-0,03$ & 0,41 & $-0,03$ & 0,41 \\
\hline
\end{tabular}

Source: data's processed by the authors based on the Carpathian Bank' financial statements during 2004-2013

After applying the multiline regression model in case of Carpatica Commercial Bank, the identified dependency relationship between return on equity on the one hand and the three endogenous factors, it proved to be an acceptable one considering the fact that the coefficient of determination was obtained around 0.9, and the value of the coefficient of determination adjusted $\mathrm{R}^{2}$ is not significantly different. As such, in case of Carpatica Commercial Bank the return on equity is 
Baltes, N. , Rodean (Cozma), M.D., (2015)

The influence of endogenous and exogenous factors on credit insitutions'return on equity

explained in a share of $87.40 \%$ by the variation of endogenous factors (the growth rate of portfolio, the growth rate of provisions and solvency ratio).

The observed values of the pattern deviate on average from the theoretical values situated on regression line with $2.29 \%$. The results of the ANOVA table show that the model can be appreciated as a good one, due to the links between the coefficient of determination $\left(\mathrm{R}^{2}=0.874\right)$, standard error $(\mathrm{S} \dot{\varepsilon}=5.24)$ and the calculated value of the F Test (Snedcor $=13,86$ ). As it is shown by the F test of significance, the null hypothesis is rejected in the model because of the value obtained 0.004 , being well below under the materiality threshold of 0.05 .

As such, regression equation is obtained in accordance with the next model:

$$
R O E_{B C C}=3.79+0.07 * R G L P-0,06 R G P+0,19 S_{r}
$$

For the chosen threshold value $\alpha=0.05$, the null hypothesis is rejected in case of two coefficients: the growth rate of the loan portfolio and the growth rate provisions (0.05> 0.003 - RCPC; 0.01 - SPC). In case of the intercept and the solvency ratio the null hypothesis can not be invalidated because the calculated $\mathrm{T}$ test value is above the chosen threshold value.

Basically, the equation's coefficients can take values between -1.61 and 9.19 intercept, 0.03 and 0.10 - the growth rate of the loan portfolio, -0.10 and -0.02 - the rate of growth of provision, -0.03 and 0.41 - the solvency ratio.

The estimated value of the growth rate of the loan portfolio 0.07 shows that a $1 \%$ increase in the loan portfolio will result in a return on equity' increase obtained by BCC with $7 \%$.

The obtained results after applying the muliliniar regression model in case of BT are summarized in the Table 3 .

As in case of Carpathian Commercial Bank, in case of Transilvania Bank the obtained regression equation is significant in its entirety. This affirmation it was proven by the obtained results that illustrated a level of the coefficient of determination $\left(\mathrm{R}^{2}\right)$ near the value of 0.9 . However, taking into account that the model has a coefficient of determination adjusted significantly different from the regression equation, it is hardly to be acceptable $\left(R^{2}=0.82\right.$ and $\left.0.73 R_{M}{ }^{2}\right)$. So it can be drawn the idea that a variation of $82 \%$ of the return on equity it is explained by the variation of the 3 internal determinants included into the equation. On average the observed values deviate from the theoretical values situated on the multiline regression with $428 \%$. Based on the obtained and summarized results in the table ANOVA, the model can be assessed as a good one, due to the links established between the coefficient of determination $(\mathrm{R} 2=0.82)$, standard error $(\mathrm{S} \dot{\varepsilon}=18.32)$ and the calculated value of $F$ test $($ Snedcor $=9.11)$. 
Baltes, N. , Rodean (Cozma), M.D., (2015)

The influence of endogenous and exogenous factors on credit insitutions'return on equity

Table no 3 - The results of the multiliniar regressions model - ROE-internal determinants in case of BT

\begin{tabular}{|c|c|c|c|c|c|c|c|c|}
\hline \multicolumn{2}{|c|}{ Regression Statistics } & & & & & & & \\
\hline Multiple R & 0,91 & & & & & & & \\
\hline R Square & 0,82 & & & & & & & \\
\hline Adjusted R Square & 0,73 & & & & & & & \\
\hline Standard Error & 4,28 & & & & & & & \\
\hline Observations & 10 & & & & & & & \\
\hline \multicolumn{9}{|l|}{ ANOVA } \\
\hline & $d f$ & $S S$ & $M S$ & $F$ & \multicolumn{2}{|c|}{ Significance $F$} & & \\
\hline Regression & 3 & 500,63 & 166,88 & 9,11 & \multicolumn{2}{|c|}{0,01} & & \\
\hline Residual & 6 & 109,95 & 18,33 & & & & & \\
\hline \multirow[t]{2}{*}{ Total } & 9 & 610,58 & & & & & & \\
\hline & Coefficients & $\begin{array}{c}\text { Standard } \\
\text { Error }\end{array}$ & $t$ Stat & $\begin{array}{c}P- \\
\text { value }\end{array}$ & $\begin{array}{c}\text { Lower } \\
95 \%\end{array}$ & $\begin{array}{c}\text { Upper } \\
95 \%\end{array}$ & $\begin{array}{l}\text { Lower } \\
95.0 \%\end{array}$ & $\begin{array}{l}\text { Upper } \\
95.0 \% \\
\end{array}$ \\
\hline Intercept & $-68,28$ & 22,14 & $-3,08$ & 0,02 & $-122,44$ & $-14,12$ & $-122,44$ & $-14,12$ \\
\hline $\begin{array}{l}\text { Growth rate } \\
\text { of the loan } \\
\text { portfolio }\end{array}$ & $-0,02$ & 0,03 & $-0,69$ & 0,51 & $-0,11$ & 0,06 & $-0,11$ & 0,06 \\
\hline $\begin{array}{l}\text { The growth } \\
\text { rate of } \\
\text { provisions }\end{array}$ & $-0,14$ & 0,03 & $-4,66$ & 0,00 & $-0,21$ & $-0,06$ & $-0,21$ & $-0,06$ \\
\hline $\begin{array}{l}\text { Solvency } \\
\text { ratio }\end{array}$ & 6,64 & 1,69 & 3,93 & 0,01 & 2,51 & 10,78 & 2,51 & 10,78 \\
\hline
\end{tabular}

Source: data's processed by the authors based on the Transilvania Bank' financial statements during 2004-2013

The probability that the null hypothesis for the regression model can be validated recorded the level of $1 \%$, being below under the significance level of 5\%.

Thus the obtained regression equation is below mentioned:

$$
R O E_{B T}=-68.28-0.02 * R G L P-0,13 R G P+6,64 S_{R}
$$

The analysis performed on the equation' coefficients revealed that for the chosen threshold of 5\%, the null hypothesis for the model coefficient can be rejected, for the growth rate of provisions and for the solvency ratio $(0.05>0.02,0.003$ and 0.008 ), while in case of the growth rate of the loan portfolio the null hypothesis is validated $(0.05<0.51)$.

The estimated value of the growth rate of the loan portfolio -0.02 indicates that a $1 \%$ increase in the loan portfolio will determine a decrease in the obtained return on equity by BT by $2 \%$.

As such it can be seen that the ROE achieved by the Commercial Bank Carpatica it is explained in a much larger proportion of the three endogenous factors analyzed, unlike ROE achieved by Transilvania Bank SA. This one can be explained by the 
Baltes, N. , Rodean (Cozma), M.D., (2015)

The influence of endogenous and exogenous factors on credit insitutions 'return on equity

fact that the economical environments have severely affected the results obtained by the two credit institutions. This fact resulted from the depreciation of all the analyzed indicators (it can be seen that the annual rate of growth of provisions is superior to the growth rate of loan portfolio, determining adverse consequences on the profitability and performance indicators).

\section{Study regarding the impact of exogenous determinants of ROE indicator obtained by Carpathian Commercial Bank and Transilvania Bank}

The external chosen factors that were included in the model are represented by gross domestic product and by the inflation rate. The motivation considered in the moment of choosing these indicators derived from the following considerations: GDP - reflects the state of the national economy at a time, affecting the ability of borrowers to repay at the maturity the commitments assumed and the inflation rate, which directly affects the purchasing power of the individuals and thus the consumption and economy.

The undertaken study, in order to identify a dependency relationship between ROE achieved by two analyzed commercial banks, on the one hand and the two exogenous factors that were introduced into the model, revealed the fact that in case of both credit institutions the hypothesis is difficult to be validated and accepted.

In order to support this result we present our following arguments:

- For both regression equations verified in case of both credit institutions, the coefficient of determination differ significantly by the coefficient of determination adjusted. (in case of BCC: $\mathrm{R}^{2}=0.30$ and $\mathrm{R}_{\mathrm{M}}{ }^{2}=0.10$, $\mathrm{BT}: \mathrm{R}^{2}=0.28$ and $\mathrm{R}_{\mathrm{M}}{ }^{2}=$ $0.07)$.

- The null hypothesis of the model is validated both for BCC (F test Significance > threshold 0.28>0.05) and for BT (Significance F (0.32)>> threshold chosen $0,05)$.

- The null hypothesis is also confirmed in case of the coefficients of the two regression equations;

- The dispersion error is not a constant one, according to diagrams 1 and 2 (in case of BT); 3 and 4 (in the case of BCC).

For both commercial banks included in the survey, the variation of the recorded return on equity is not justified by the variations of GDP and inflation rate. This result requires and encourages a deeper research on the both banks' credit portfolios, on the landed sectors and also on the non-performing loan rate registered separately on each financed sector in relation to its contribution to GDP. 
Baltes, N. , Rodean (Cozma), M.D., (2015)

The influence of endogenous and exogenous factors on credit insitutions 'return on equity

\section{Diagram 1 and 2 - Residual Analysis in case of exogenous factors and return on equity recorded by BT \\ PIB Residual Plot

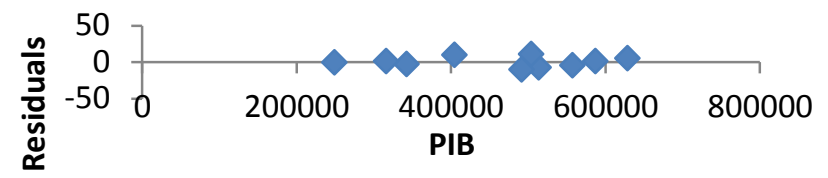

\section{Rata inflatiei Residual...}

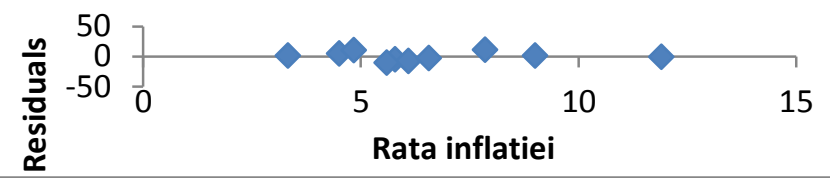

Source: data's processed by the authors based on the Transilvania Bank' Annual Reports and the offered data by National Institute of Statistics during 2004-2013

Diagram 3 and 4 - Residual Analysis in case of exogenous factors and return on equity recorded by $\mathrm{BCC}$

\section{PIB Residual Plot}

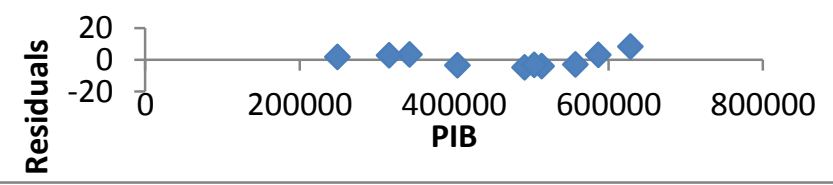

\section{Rata inflatiei Residual...}

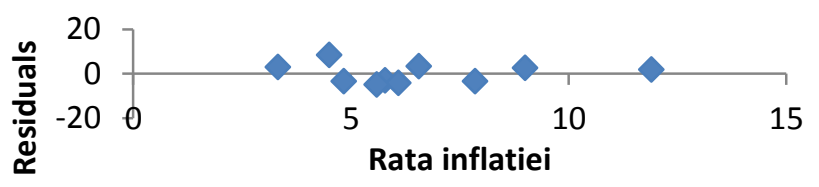

Source: data's processed by the authors based on the Carpathian Bank' Annual Reports and the offered data by National Institute of Statistics during 2004-2013 
Baltes, N. , Rodean (Cozma), M.D., (2015)

The influence of endogenous and exogenous factors on credit insitutions 'return on equity

\section{Conclusions}

The present study showed that in case of both credit institutions, the evolution of the return on equity is largely explained by the evolution of endogenous factors, while the identified regression equation for exogenous factors was invalidated.

The different evolution registered by the indicators in case of both analyzed commercial banks is due to the adopted strategy, target market, credit policy, etc., also reflected on credit portfolios.

To improve the return on capital, we consider that both credit institutions should improve their solvency ratio, the growth rate of the loan portfolio and it's quality of the loan portfolio.

\section{Acknowledgments:}

This work was supported by the strategic grant POSDRU/159/1.5/S/133255, Project ID 133255 (2014), co-financed by the European Social Fund within the Sectorial Operational Program Human Resources Development 2007 - 2013

\section{References:}

1. Khrawish, H. A. (2011). Determinants of commercial banks performance: evidence from Jordan. International Research Journal of Finance and Economics (81), 148-159. Retrieved from http://www.internationalresearchjournaloffinanceandeconomics.com

2. Navapan, K., \& Tripe, D. (2003). An exploration of the relationship between bank capital levels and return on equity. Proceeding of the 16th Australasian Finance and Bank. Conf. AFBC'03). Palmerston North, pp.1-15.

3. Popa, M., Multiline Regression, document available online: http://www.mpopa.ro/statistica master/05 statm regresia\%20mutipla.pdf, accesed in 05.03.2015

4. Rajan, R., 2005. Has financial development made the world riskier? Paper presented at the Federal Reserve Bank of Kansas City Economic Symposium at Jackson Hole.

5. Shaher, T. A., Kasawneh, O., \& Salem, R. (2011). The major factors that affect banks' performance in Middle Eastern countries. Journal of Money, Investment and Banking (20), 101-109. Retrieved from http://www.eurojournals.com/JMIB.htm

6. Thampy, A. (2004). BIS capital standards and supply of bank loans. Working Paper Series. Retrieved from http://ssrn.com/abstract=561723

7. Annual Reports of Carpathian Bank SA during 2004-2013, available online: www.carpatica.ro 
Baltes, N. , Rodean (Cozma), M.D., (2015)

The influence of endogenous and exogenous factors on credit insitutions 'return on equity

8. Annual Reports of Transilvania Bank SA during 2004-2013, available online: www.bancatransilvania.ro

9. www.insse.ro

10. National Bank of Romania, Financial Stability Report, 2014, available online: http://www.bnro.ro/Publicatii-periodice-204.aspx 